\title{
Is higher mean platelet volume an additional predictive marker of oligohydramnios and polyhydramnios?
}

\section{Yüksek ortalama trombosit hacmi oligohidramnios ve polihidramnios için ek bir prediktif belirteç midir?}

\author{
Neriman Çetin Benli, ${ }^{1}$ (1) Sibel Mutlu, ${ }^{2}$ (1) Abdulkerim Yıldız, ${ }^{3}$ (i) Ali Ramazan Benli \\ 'Department of Family Medicine, Bağlar Family Health Center, Safranbolu, Karabük, Turkey \\ ${ }^{2}$ Departments of Gynecology and Obstetric, Karabük University Faculty of Medicine, Karabük, Turkey \\ ${ }^{3}$ Department of Hematology, Dışkapı Yıldırım Beyazıt Training and Research Hospital, Ankara, Turkey \\ ${ }^{4}$ Departments of Family Medicine, Karabük University Faculty of Medicine, Karabük, Turkey
}

\begin{abstract}
Introduction: Amniotic fluid abnormalities are the leading cause of fetal morbidity and mortality. The aim of this study was to investigate whether prepartum mean platelet volume (MPV) is associated with and a predictable marker for oligohydramnios $(\mathrm{OHA})$ and polyhydramnios (PHA).

Methods: In this retrospective study, an examination was made of the records of patients who were monitored and gave birth at Karabuk Training and Research Hospital Gynecology and Obstetrics Clinic in 2014-2015. Patients with isolated OHA and PHA were included in the study group and those with normal amnion fluid volume (AFV) in the control group. A record was made of age, obstetric and clinical history, smoking, alcohol consumption, laboratory test results and ultrasonography reports in the third trimester of the pregnancy.

Results: A total of 284 pregnant women were included in the study. The MPV levels of the OHA and PHA groups were significantly higher than those of the normal group $(p=0.000)$. There was no significant difference was observed between the OHA and PHA groups $(p=0.20)$. MPV $>8.4$ accurately differentiated AFV (AUC: $68.8 \%$, sensitivity: $78.6 \%$, specificity: $59.1 \%$ ). MPV $>8.0$ accurately differentiated OHA (AUC: 67.1\%, sensitivity: $84.4 \%$, specificity: 50.0\%). MPV > 8.5 accurately differentiated PHA (AUC: $70.2 \%$, sensitivity: $79.0 \%$, specificity: $61.4 \%$ ).
\end{abstract}

Discussion and Conclusion: The result of the current study shows that screening MPV has a predictive value for $\mathrm{OHA}$ and PHA in pregnancies without complications or fetal anomaly.

Keywords: Amniotic fluid; mean platelet volume; oligohydramnios; polyhydramnios.
Özet

Amaç: Amniyotik sıvı anomalileri, fetal morbidite ve mortalitenin önde gelen nedenleridir. Bu çalışmanın amacı, prepartum ortalama trombosit hacminin (MPV), oligohidramnios (OHA) ve polihidramnios (PHA) ile ilişkisini inceleyerek prediktif bir marker olup olmadığını araştırmaktır.

Gereç ve Yöntem: Bu retrospektif çalışmada, 2014-2015 yılları arasında Karabük Eğitim ve Araştırma Hastanesi Kadın Hastalıkları ve Doğum Kliniği'nde izlenen ve doğum yapan hastaların kayıtları incelenmiştir. İzole OHA ve PHA'lı hastalar çalışma grubuna, normal amniyon sIVISı hacmine (AFV) sahip hastalar ise kontrol grubuna dahil edildi. Gebeliğin üçüncü trimesterinde yaş, obstetrik ve klinik öykü, sigara kullanımı, alkol tüketimi, laboratuvar test sonuçları ve ultrasonografi rapor sonuçları kaydedildi.

Bulgular: Çalışmaya toplam 284 gebe dahil edildi. OHA ve PHA gruplarının MPV seviyeleri kontrol grubuna göre anlamlı derecede yüksekti $(p<0.05)$. OHA ve PHA grupları arasındaistatistiksel olarak anlamlı fark görülmedi ( $p>0.05)$. MPV> 8.4, AFV'yi doğru bir şekilde farklılaştırdı (AUC: \%68.8, duyarlılık: \%78.6, özgüllük: \%59.1). MPV> 8.0, OHA'yı doğru şekilde farklılaştırdı (AUC: \%67.1, duyarlılık: \%84.4, özgüllük: \%50.0). MPV> 8.5, PHA'yı doğru bir şekilde farklılaştırdı (AUC: \%70.2, duyarlıık: \%79.0, özgüllük: \%61.4).

Sonuç: Bu çalışmanın sonuçları; MPV taramasının komplikasyon veya fetal anomali olmayan gebeliklerde $\mathrm{OHA}$ ve PHA için prediktif bir değere sahip olduğunu göstermektedir.

Anahtar Sözcükler: Amniyotik sıvl; ortalama trombosit hacmi; oligohidramnios; polihidramnios 
A mniotic fluid (AF) is kept in a dynamic equilibrium and volume obtained from total flow (from fetal urine and lung fluid) and outflow of fluid from amniotic space (fetal swallowing and intramembranous absorption). It provides a supportive environment for growth, protection from infection and trauma. It allows fetal movement therefore promotes the development of musculoskeletal system. ${ }^{[1]} \mathrm{AF}$ volume (AFV) is an indicator of fetal well-being and is an important measurement during antenatal fetal tests in the second and third trimesters of pregnancy. If the actual volume of AFV is less than $500 \mathrm{~mL}$, it is defined as oligohydramnios. If it is greater than $2000 \mathrm{ml}$, it is defined as polyhydramnios. It was reported before that oligohydramnios may be associated with some abnormalities such as meconium staining, congenital anomalies, growth retardation and fetal asphyxia. ${ }^{[2]}$ In general, approximately 3 to $5 \%$ of pregnancies are complicated by oligohydramnios. Some of the cases are diagnosed in the absence of maternal-fetal risk factors and they defined as 'isolated oligohydramnios.[1] Total incidence of polyhydramnios ranges from 0.2 to $2 \%$ as reported from many studies. ${ }^{[3]}$ Although most of the cases are idiopathic, fetal malformations and genetic anomalies, maternal diabetes mellitus and hypercalcemia, multiple pregnancies, fetal anemia, neuromuscular disorders, and some others are seem to be risk factors. ${ }^{[2,4]}$

Mean platelet volume (MPV) is an indicator of platelet size and demonstrates platelet activity. Platelets with larger MPV are known as younger and more reactive. It was shown before that they contain more dense granules, secrete more granules than platelets with lower MPV. ${ }^{[5]}$ There are some changes in platelet size and count during pregnanacy. Firstly, lifespan of platelets decreases and therefore MPV increases minimally. Also platelet count in the peripheral blood decreases due to increased platelet consumption in the uterus. ${ }^{[6]}$ Although several studies have examined MPV levels in problems which develop during pregnancy, to the best of our knowledge there has been no previous study of the relationship between MPV and the development of AFV abnormalities. Therefore, in this study it was investigated whether prepartum MPV is associated with and a predictable marker for the development of $\mathrm{OHA}$ and $\mathrm{PHA}$.

\section{Materials and Method}

\section{Study design and subject selection}

In this retrospective study, an examination was made of the records of patients who were monitored and gave birth at Karabuk Training and Research Hospital Gynecology and Obstetric Clinic in 2014-2015. Complicated cases (e.g. abruptio placenta, pre-eclampsia, eclampsia), patients with known thrombotic or hematological disease (e.g. gestational or immune thrombocytopenia), use of any medication, known renal or hepatic insufficiency, chronic inflammatory disease, alcohol use, cardiac failure, known coronary artery disease, essential hypertension, diabetes mellitus, Rh incompatibility and fetal and placental anomalies, non-isolated $\mathrm{OHA}$ and $\mathrm{PHA}$, or multiple gestation pregnancy were excluded from the study. Patients with isolated OHA and PHA were included in the study group and those with normal amnion fluid volume (AFV) in the control group. A record was made of age, obstetric and clinical history, smoking, alcohol consumption, laboratory test results and ultrasonography reports in the third trimester of the pregnancy. The third trimester was considered as the period from the $28^{\text {th }}$ week of pregnancy until delivery.

\section{Sonographic examination}

In cases where AFV changes were determined, these were confirmed by a second experienced ultrasonographer, to avoid any doubt in the obstetric department. Amnion fluid volume of $<2 \mathrm{~cm}$ in a single quadrant by vertical measurement or $<5 \mathrm{~cm}$ total in four quadrants was evaluated as oligohydramnios. Amnion fluid volume of $>25 \mathrm{~cm}$ total in four quadrants was evaluated as polyhydramnios. AFV of $25-5 \mathrm{~cm}$ was evaluated as normal.

\section{Statististical analysis}

All statistical analyses were performed using R software 3.2.3 (R Development Core Team R 2015). Conformity to normal distribution of continuous variables was evaluated using the Anderson Darling Test. Variables with normal distribution were stated as mean and standard deviation and non-normally distributed variables as median values (minimum-maximum). Between groups variations of normally distributed variables were compared using One-way ANOVA and the least significant differences (LSD) test was applied as a post-hoc test. Non-normally distributed variables were compared using the Kruskal-Wallis test and the Wilcoxon Rank Sum test was used as a post-hoc test. To obtain a threshold value to predict AFV changes using MPV values, receiver operating characteristics curve (ROC) analyses were performed using "Epi" library of $\mathrm{R}$ software. The protocol of the study was approved by the Duzce University of Medical Sciences Local Research Ethics Committee at 08.02.2016 with registration number 2016/02.

\section{Results}

A total of 284 pregnant women met the criteria and were included in the study as $55 \mathrm{OHA}, 141 \mathrm{PHA}$, and 88 normal AFV. The characteristics of the groups including age, gestational weeks, gravida, parity and abortions are shown in Table 1. A difference in median age was determined only between the normal and PHA groups $(p=0.001)$.

The values of platelets, plateletcrit, MPV, hemoglobin and hematocrit distribution of each group are shown in Table 2. The MPV levels of the OHA and PHA groups were significantly higher than those of the normal group $(p<0.001$ and $p<0.001$, respectively), although no difference was observed between the OHA and PHA groups $(p=0.20)$. MPV values of $>8.4$ accurately differentiated AFV (AUC: $68.8 \%$, sensitivity: $78.6 \%$, specificity: $59.1 \%$ ) (Fig. 1). MPV values of $>8.0$ accurately differentiated OHA (AUC: $67.1 \%$, sensitivity: $84.4 \%$, specificity: $50.0 \%$ ). MPV values of $>8.5$ accurately differentiated PHA (AUC: $70.2 \%$, sensitivity: $79.0 \%$, specificity: $61.4 \%$ ). 
Table 1. Demographic and clinical characteristics of study groups

\begin{tabular}{|c|c|c|c|c|}
\hline & Control $(n=88)$ & OHA $(n=55)$ & PHA $(n=141)$ & $\mathbf{p}$ \\
\hline Gestational week at examine time & $33.3 \pm 1.1$ & $33.6 \pm 1.2$ & $32.9 \pm 1.0$ & $0.36^{* *}$ \\
\hline Parity & $2(0-7)$ & $2(0-6)$ & $2(0-6)$ & $0.89 *$ \\
\hline Smoking & $9.09 \%$ & $10.90 \%$ & $9.92 \%$ & $0.08^{* *}$ \\
\hline
\end{tabular}

OHA: Oligohydramnios; PHA: The values given as mean \pm sd; median (min.-max.) or percentile (\%). ${ }^{*}$ Kruskal Wallis Test; ${ }^{* *}$ One way ANOVA.

Table 2. Descriptive statistics for hematological values of the groups

\begin{tabular}{lccc} 
& Control $(\mathbf{n}=\mathbf{8 8})$ & OHA $(\mathbf{n}=\mathbf{5 5})$ & PHA (n=141) \\
\hline $\mathrm{Hb}(\mathrm{g} / \mathrm{dL})$ & $11.91 \pm 1.45$ & $11.88 \pm 1.60$ & $11.60 \pm 1.30$ \\
$\mathrm{Hct}(\%)$ & $35.42 \pm 3.92$ & $36.48 \pm 4.17$ & $35.90 \pm 3.76$ \\
$\mathrm{Plt}\left(\times 10^{3} / \mathrm{mm}\right)$ & $234.500^{\mathrm{a}}(130.000-504.000)$ & $210.000^{\mathrm{b}}(149.000-354.000)$ & $218.000^{\mathrm{b}}(130.000-385.000)$ \\
$\mathrm{Pct}(\%)$ & $0.180(0.070-0.310)$ & $0.180(0.120-0.340)$ & $0.19^{\ddagger}$ \\
$\mathrm{MPV}(\mathrm{fL})$ & $8.000(5.100-11.400)^{\mathrm{a}}$ & $8.700(6.700-10.700)^{\mathrm{b}}$ & $\mathbf{0 . 0 4 ^ { \dagger }}$ \\
\hline
\end{tabular}

[Mean \pm SD for normally distributed variables, median (min.-max.) for non-normally distributed variables]; Hb: Hemoglobin; Hct: Haematocrit; Plt: Platelet; Pct: Plateletcrit; MPV: Mean platelet volume; OHA: Oligohydramnios; PHA: ${ }^{+}$Determined by Kruskall-Wallis Test. Within each row not sharing common superscript are significantly different ( $p<0.05$ ) as determined by Mann-Whitney U Test. ${ }^{\ddagger}$ Obtained from ANOVA. Within each row not sharing common superscript are significantly different $(p<0.05)$ as determined by Least Significant Differences.

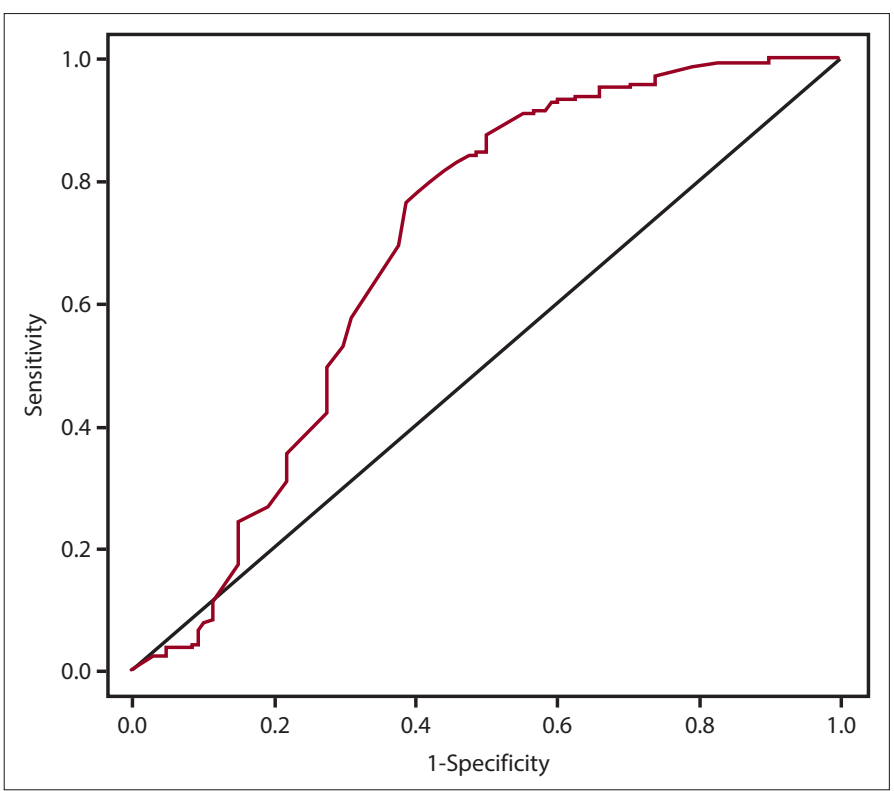

Figure 1. ROC curve for mean platelet volume [AUC: $0.693(95 \% \mathrm{Cl}$ : $0.617-0.769)]$.

The results showed that the OHA and PHA groups had higher median PLT count than the normal group $(p=0.023$, $p=0.032$, respectively), but the differences were not statistically significant between OHA and PHA $(p=0.51)$ No statistically significantly differences were observed between the groups in respect of hemoglobin and hematocrit values $(p=0.19, p=0.25$ respectively). No statistically significant dif- ferences were observed between the groups in respect of plateletcrit values $(p=0.52)$.

\section{Discussion}

In the current study, it was investigated whether prepartum MPV is associated with OHA and PHA. The results showed that MPV levels were higher in pregnant women with OHA and PHA than those who had normal AF volumes. MPV values of $>8.4$ accurately differentiated AFV and MPV values of $>8.0$ accurately differentiated OHA. MPV values of $>8.5$ accurately differentiated PHA.

At the later periods of pregnancy, many clotting factors increased whereas there is reduction in fibrinolytic activity. Therefore it results in a hypercoagulable state for pregnant woman considered as a form of acquired thrombohilia. ${ }^{[7]}$ There are many previous studies regarding the clinical use of MPV in pregnant women. Han et al. reported that, compared to early pregnancy, MPV and fibrinogen levels increase during late pregnancy while activated partial thromboplastin time (APTT), prothrombin time (PT), thrombin time (TT) and platelet count decrease. ${ }^{[8]}$ However, increased APTT, TT, MPV and $\mathrm{D}$-dimer levels were determined in preeclampsia $(\mathrm{PE}) \mathrm{pa}$ tients during the third trimester. They suggested that PE may cause complex abnormalities in the endogenous coagulation pathways and resulted in platelet comsumption. Therefore both TT and MPV can be used as early markers for the beginning and severity of $\mathrm{PE} .{ }^{[8]}$ Several studies have been conducted on MPV in patients with pre-eclampsia and hypertension and 
many of them have demonstrated elevated levels of MPV in these patients..$^{[9-12]}$ The underlying mechanism is not clear but insufficient uteroplacental circulation due to failure of trophoblastic invasion of the spiral arteries is considered to be the most important factor in hypertension. Also, uncontrolled intravascular platelet activation and fibrin deposition play a role in decreased platelet count. ${ }^{[6]}$

There have also been several studies which have indicated that MPV is increased in GDM and researchers have suggested that monitoring MPV may predict whether a pregnant women will develop GDM or not. ${ }^{[13-16]}$ Another issue is that, higher platelet activity may lead to hypercoagulability in the placental bed which may cause fatal pregnancy complications. Because the higher MPV values indicates higher platelet activity, it can be used a predictive factor for complications. ${ }^{[6]}$ Umazume et al. reported that there was higher MPV and platelets were more reactive in the $2^{\text {nd }}$ trimester of twin pregnancies than in singleton pregnancies. ${ }^{[17]}$ In another study, Karaman et al. showed that MPV is lower in tubal ectopic pregnancy than intrauterine pregnancy and they suggested a relationship between MPV and inflammation at the implantation site of tuba uterina. ${ }^{[18]}$

To the best of our knowledge, there is no study regarding MPV levels in OHA and PHA. Amniotic fluid abnormalities are the main causes of fetal morbidity and mortality and considered to be responsible for increased complications during labor. ${ }^{[2]}$ As mentioned above there are a number of potential etiologies in $\mathrm{OHA}$ and $\mathrm{PHA}$, and also many situations which cause an increase in MPV levels during pregnancy. Therefore, only pregnant patients with isolated $\mathrm{OHA}$ and PHA were enrolled in the current study to avoid from confounding factors. The underlying mechanism is not clear however chronic severe placental insufficiency is known to cause a decrease in amniotic fluid independent of reduced fetal urine output. ${ }^{[19]}$ As a result of villus vascular anomalies that cause chronic placental insufficiency; platelet production and destruction are increased and secondary to this, thrombocytopenia and increase in MPV levels maybe seen. ${ }^{[20]}$

On the other hand, there are some studies invesitgating the role of MPV in placental level. Buyukkaya et al. found an association between placental grade and MPV, suggesting that an increase in MPV value is an indicator of microthrombotic changes in placental level. They also indicated that it may be valuable for increase in placental grade. ${ }^{[7]}$ In a similar study, they found a relationship between $\mathrm{OHA}$ and high placental grade, plasma viscosity and coagulation parameters. ${ }^{[21]}$ We already know that platelets have a major role in vascular homeostasis and induce early inflammatory reaction as the endothelial cell injury occurs. ${ }^{[22]}$ In the case of OHA and PHA, placental damage can occur and it may change the platelet size. However, in the current study, as patients with placental anomaly, and those with placental grade not compatible with the gestational week were not included. Therefore, it can be said that elevated MPV was not related to placental dysfunction.

\section{Limitations of the study}

Most important limitation was its restrospective design and smaller number of the patients. The MPV level should be assessed in pregnancy-related diseases such as preeclampsiagestational diabetes and compared with the current results. It may be a confusing result that MPV values of disease groups were lower than control group.

\section{Conclusion}

The results of the current study show that screening MPV has predictive value in $\mathrm{OHA}$ and $\mathrm{PHA}$ in pregnancies without complications or fetal anomaly. Furthermore, to the best of our knowledge, this is the first study showing a relationship between AFV changes and routine maternal laboratory test results. Finally, in cases of OHA and PHA, obstetricians should be alert to maternal systemic diseases (e.g. pre-eclampsia) and fetal distress. MPV can be assessed in all healthcare centers as it is an easily available and cheap test and can be used an indicator of some clinical conditions. Therefore, if MPV is detected higher than normal range in the first stage of health care, the pregnant patient should be referred to a advanced center for assessment of AFV.

Conflict of interest: The authors report no conflict of interests.

\section{References}

1. Gizzo S, Noventa M, Vitagliano A, Dall'Asta A, D'Antona D, Aldrich $C J$, et al. An Update on Maternal Hydration Strategies for Amniotic Fluid Improvement in Isolated Oligohydramnios and Normohydramnios: Evidence from a Systematic Review of Literature and Meta-Analysis. PloS one. 2015;11:10-12.

2. Benzer N, Tazegül Pekin A, Yılmaz SA, Kerimoğlu ÖS, Doğan NU, Çelik Ç. Predictive value of second and third trimester fetal renal artery Doppler indices in idiopathic oligohydramnios and polyhydramnios in low-risk pregnancies: A longitudinal study. Journal of Obstetrics and Gynaecology Research. 2015;41:523-528.

3. Aviram A, Salzer L, Hiersch L, Ashwal E, Golan G, Pardo J, et al. Association of isolated polyhydramnios at or beyond 34 weeks of gestation and pregnancy outcome. Obstetrics \& Gynecology. 2015; 125:825-832.

4. Hamza A, Herr D, Solomayer EF, Meyberg-Solomayer G. Polyhydramnios: Causes, Diagnosis and Therapy. Geburtshilfe Frauenheilkd. 2013;73(12): D1241-D1246.

5. Balbaloglu O, Korkmaz M, Yolcu S, Karaaslan F, Beceren NG. Evalution of mean platelet volume (MPV) levels in patient with synovitis associated with knee osteoarthritis. Platelets. 2014;25:81-85.

6. Juan P, Stefano G, Antonella S, Albana C. Platelets in pregnancy. Journal of Prenatal Medicine. 2011;5:90.

7. Buyukkaya R, Buyukkaya A, Erkan M, Ozturk B, Yazgan S. Relationship between placental grade and mean platelet volum. Platelets. 2014;25:229-233.

8. Han L, Liu X, Li H, Zou J, Yang Z, Han J, et al. Blood coagulation parameters and platelet indices: changes in normal and preeclamptic pregnancies and predictive values for preeclampsia. PLoS One. 2014;2:1-14.

9. Arduini D, Rizzo G. Fetal renal artery velocity waveforms and am- 
niotic fluid volume in growth retarded and post-term fetuses. Obstet Gynecol. 1991;77:370-373.

10. Leibovitch L, Kuint J, Rosenfeld E, Schushan-Eisen I, WeissmannBrenner A, Maayan-Metzger A. Short-term outcome among term singleton infants with intrapartum oligohydramnios. Acta Pædiatrica. 2012;101:727-730.

11. Özdemirci Ş, Başer E, Kasapoğlu T, Karahanoğlu E, Kahyaoglu I, Yalvaç S, et al. Predictivity of mean platelet volume in severe preeclamptic women. Hypertens Pregnancy. 2016;17:1-9.

12. Moraes D, Munhoz TP, Pinheiro da Costa BE, Hentschke MR, Sontag F, Silveira Lucas $L$, et al. Immature platelet fraction in hypertensive pregnancy. Platelets. 2016;27(4):333-337.

13. Iyidir OT, Degertekin CK, Yilmaz BA, Toruner FB, Akturk M, Arslan $M$. Elevated mean platelet volume is associated with gestational diabetes mellitus. Gynecol Endocrinol. 2014;30(9):640-643.

14. Sak ME, Soydinç HE, Ozler A, Evsen MS, Turgut A, Sak S, et al. Platelet profile in patients with gestational diabetes: a retrospective study. J Turk Ger Gynecol Assoc. 2012;13(4):223-226.

15. Erikci AA, Muhcu M, Dundar O, Oztürk A. Could mean platelet volume be a predictive marker for gestational diabetes mellitus? Hematology. 2008;13:46-48.

16. Gioia S, Cerekja A, Larciprete G, Vallone C, Demaliaj E, Evangelista $M T$, et al. Gestational diabetes: is it linked to platelets hyperactiv- ity? Platelets. 2009;20:140-141.

17. Umazume T, Yamada T, Morikawa M, Ishikawa S, Furuta I, Koyama $\mathrm{T}$, et al. Platelet reactivity in twin pregnancies. Thromb Res. 2016;138:43-48.

18. Karaman E, Çim N, Alkış İ, Yıldızhan R, Elçi G. Evaluation of mean platelet volume in unruptured ectopic pregnancy: A retrospective analysis. J Obstet Gynaecol. 2016;36(5):622-625.

19. Gagnon R, Harding R, Brace RA. Amniotic fluid volume and fetal urinary response to severe placental insufficiency in sheep. Am J Obstet and Gynecol. 2002;186:1076.

20. Baschat AA, Gembruch U, Reiss I, Gortner L, Weiner CP, Harman CR. Absent umbilical artery end-diastolic velocity in growth-restricted fetuses: a risk factor for neonatal thrombocytopenia.Obstet Gynecol 2000;96:162-166.

21. Battaglia C, Artini PG, Ballestri M, Bonucchi D, Galli PA, Bencini S, et al. Hemodynamic, hematological and hemorrheological evaluation of post-term pregnancy. Acta obstetricia et gynecologica Scandinavica. 1995;74:336-340.

22. Tüzün A, Keskin O, Yakut M, Kalkan C, Soykan I, et al. The predictive value of mean platelet volume, plateletcrit and red cell distribution width in the differentiation of autoimmune gastritis patients with and without type I gastric carcinoid tumors. Platelets. 2014;25:363-366. 